Working Papers on The Nature of Evidence:

How Well Do 'Facts' Travel?

No. 03/05

\title{
Experimental Farming and Ricardo's Political Arithmetic of Distribution
}

\author{
Mary S. Morgan
}

(C) Mary S. Morgan

Department of Economic History London School of Economics 


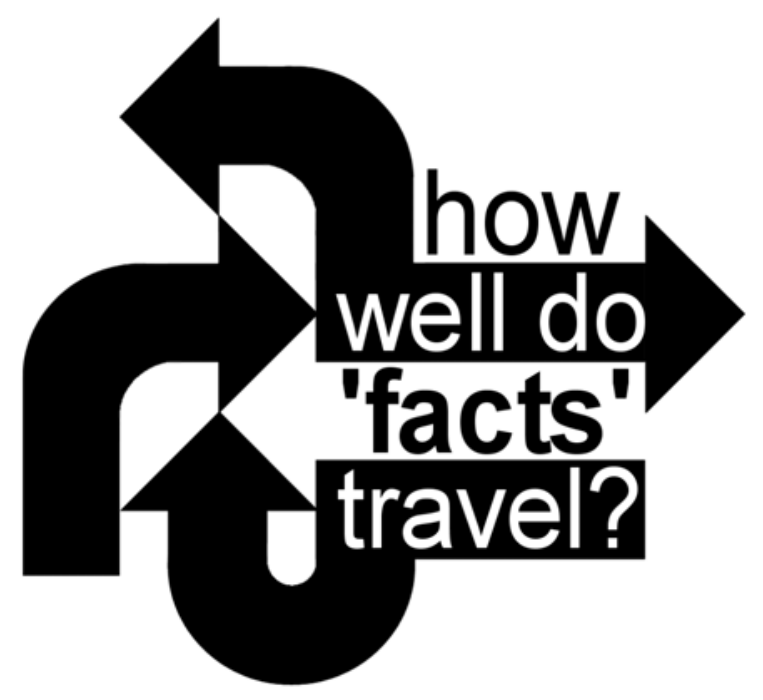

"The Nature of Evidence: How Well Do 'Facts' Travel?" is funded by The Leverhulme Trust and the ESRC at the Department of Economic History, London School of Economics.

For further details about this project and additional copies of this, and other papers in the series, go to:

http://www.Ise.ac.uk/collection/economichistory/

Series Editor:

Dr. Jonathan Adams

Department of Economic History

London School of Economics

Houghton Street

London, WC2A $2 \mathrm{AE}$

Tel: $\quad$ +44 (0) 2079556727

Fax: $\quad$ +44 (0) 2079557730 


\title{
Experimental Farming and Ricardo's Political Arithmetic of Distribution $^{1}$
}

Mary S. Morgan

\begin{abstract}
The development of David Ricardo's economic theory of distribution the laws that determine the share of output between the economic classes depended on specific connections at several levels between two practical sciences of the early $19^{\text {th }}$ century, namely experimental agriculture and political economy. This paper shows how Ricardo, one of the foremost British economists of his day, combined his empirical knowledge of farming and agricultural experiments to develop both the content and method of Classical economics. The method of argument he developed depended upon numerical experiments that mirrored, in form and experience, the experimental accounts from agricultural science. The content of his arguments, and his derivation of the laws of distribution, depended critically on the effect of increased labour input into agriculture. This apparently hypothetical case was in fact a real question of political economy addressed by farming experiments within the context of the contemporary "spadehusbandry" debate.
\end{abstract}

\section{Farming matters, economics matters}

The late $18^{\text {th }}$ and early $19^{\text {th }}$ centuries were an age of experimental farming in Britain. Experiments were undertaken not just in the interests of science or to expand agricultural knowledge for its own sake but to improve the productivity and so output of the farming sector. There was a strong proselytizing - even missionary - element in these activities;

\footnotetext{
${ }^{1}$ Versions of this paper have been given to my departmental colleagues in May 2003, at the History of Economics Meeting at Duke in July 2003, at the Economic History Seminar, Oxford (November 2003) and Seminar on "Knowledge and Society", Institute of Historical Research, London and the "Histoire et Philosophie de la Mesure" Université Paris 7, (December 2003) and the University of California, San Diego, Science Studies Group (January, 2004). I am grateful for comments on all these occasions, and to Peter Howlett and Stephan Epstein for readers' comments. My thanks also to Lesley Stringer, Márcia Balisciano and especially Xavier López del Rincón Troussel, for splendid research assistance on the paper; and to librarians at the University Library in Cambridge and Goldsmiths Library (Senate House) in London for help with Ricardo papers and pamphlets. Comments are most welcome to m.morgan@lse.ac.uk
} 
successful experiments were to provide information and advice, even exemplary procedures for others to follow. Experimental reports such as the 500-odd found in Arthur Young's Farmer's Tours of the 1770s and William Marshall's Experiments and Observations Concerning Agriculture and the Weather (1779) went alongside agricultural handbooks outlining best practise, such as Alex Beatson's A New System of Cultivation (1820/21). Experimental investigations in the first two decades of the $19^{\text {th }}$ century (the period with which this paper is particularly concerned) ranged over animal husbandry, fertiliser testing, cultivation methods, work organisation, machine performance, etc., just as they had earlier focussed on the virtues of animal breeding and the importance of drainage, of new crops and crop rotation. Technical change based on such experiments was an on-going process. For example, crop rotations following the "Norfolk System" introduced in the $18^{\text {th }}$ century were widely known, and used, but the best rotation for any given locality was still subject to experimental activity in the early $19^{\text {th }}$ century. ${ }^{2}$

There was also a political consciousness: a number of the Whig aristocracy, owners of large land holdings, were very intent on improvement and active in developing their own experimental farms. Their great agricultural shows and events, particularly those held at $\mathrm{Mr}$

\footnotetext{
${ }^{2}$ County surveys formed perhaps the main body of agricultural information of the day from which this variation can be understood. Marshall's county reports to the Board of Agriculture in the $2^{\text {nd }}$ decade of the century - the exact period of discussion for Ricardo's work here - followed a pattern of division into "natural economy" (soil, climate, etc.), "political economy" (markets, transport, taxes, etc.), "rural economy" (institutions such as tenure, rights, etc.) and "agriculture" (crops, labourers, etc.). For a recent article on the scientific status of the county surveys undertaken by Young and by Marshall, see Brunt (unpublished). For a recent review and reassessment of the agricultural revolution see Overton, 1996 (and for specific chapters on innovating techniques of the period, see G.E. Mingay's (1989) edited Vol VI in The Agrarian History of England and Wales). For Young's reporting of experimental farming, see Mingay, 1975, chapter II:4. Good examples of specific contemporary reports of technical matters, such as crop rotation, can be found in The Farmer's Journal of the period (for example, September 22 ${ }^{\text {nd }}, 1810$ ( $p$ 176); September $14^{\text {th }}, 1812$ ( $p$ 403) and November $1^{\text {st }}, 1813$ (front page).
} 
Coke's (later Earl of Leicester) estate at Holkham Hall, Norfolk, and the Duke of Bedford at Woburn, designed to report best agricultural practices, were high points of the social, political and agricultural season in the early years of the $19^{\text {th }}$ century. Experimental agriculture thus occupied a secure location within a politically forceful, landowning and farming, elite. The personal interest shown in farming by George III had turned it into a fashionable pursuit and the new agricultural societies provided institutional entrepreneurship. ${ }^{3}$

It was these "great improvers" of the $1780-1820$ period who made the most evident progress in agricultural knowledge while investigative laboratory work lagged a little behind. ${ }^{4}$ The scientific experimental tradition from chemistry was revitalised by the Board of Agriculture's establishment of an annual course of lectures by Humphry Davy in 1803 which lasted until 1812. These were published in 1813 as his hugely successful Elements of Agricultural Chemistry. But scientific work complemented rather than replaced the work of practical field experimenters for it was not necessarily regarded as a different kind of endeavour. Accounts of experimental activities and findings called up the work of chemists such as Dr Priestley alongside those of famous agricultural commentators such as Arthur Young and practical experimentalists such as William Grisenthwaite whose $A$ New Theory of Agriculture of 1819 also appeared as a series of letters in the Farmers' Journal. ${ }^{5}$ Davy's own Elements of Agricultural Science interwove the agricultural experimental farming reports from the Whig landowners with

\footnotetext{
${ }^{3}$ See "Agricultural Literature and Societies" by Nicholas Goddard, Chapter III in Mingay (1989).

${ }^{4}$ See Russell (1966), p 67, and Chapters II and III more generally for an account of the early history of experimental work in farming and agricultural science.

${ }^{5}$ His letters can be found, for example, in the issues of September $7^{\text {th }}$ and $21^{\text {st }}$ in 1818 addressed to "Mr Coke".
} 
the reports from Young and findings from eminent scientists such as Humboldt and Gay Lussac.

This experimental farming movement involved book learning and the "theory" of agricultural science, but drew as well upon experience from "the practical farmer", for any interested farmer could join in this agricultural science by experimenting on his own land and write to report his findings to the farming newspapers of the day. This was not necessarily high science, nor did it require the huge investments of the wealthy landowners Significantly, experimental reports by practising farmers and landowners (as opposed to those by "scientists") that found their way into the public domain described not just the agricultural experiment and its outcomes, but the associated costs and profits. Experimental reports were sometimes reported as a financial account, and if farmers reporting "successful" experiments did not provide the monetary arithmetic that demonstrated increased profit as well as productivity, they found their claims of "improvement" open to question.

While farmers, landowners (large and small) and chemists were following the experimental furrow in agriculture, the two big issues for political economists of the day were the population question and the corn laws. The problem of the apparently explosive growth of population was prevalent on the tongues of the chattering intelligentsia and evoked a considerable literature. But for historians of economics, it has been most intimately connected with the work of parson Robert Malthus. ${ }^{6}$ Their privileging of his position hangs on the concise form in which he outlined his basic theory - indeed its appealing and simple numerical form - and the ways in which he connected that theory with both the wider economic questions of growth and stagnation, and the shorter-run periods of misery and comparative well-being. Malthus suggested that we would not 
necessarily be able to observe these shorter cycles in population, but might see cycles in wages and prices as they fluctuated around the supposed long run constraint fixed by the ability of nature, and so farmers, to provide food for the rapidly growing population.

The issue of the corn laws was perhaps the most important policy question in political economy. Though legislators could fudge the issue between the tariff protection and the free import of corn by adopting partial protection, there was no apparent middle way for political economists. Reasoning about the matter forced them to line up on one side or the other, seeing either benefits or evils in that legislation. Whereas Malthus and David Ricardo, the two major figures in the field of British economics at that time, found little to argue over population, they disagreed over the corn laws. Ricardo was for their abolition, while Malthus was for keeping them. Ricardo's analysis against the corn laws was based on his rent theory. Rent theory in turn formed the basis of his theory of distribution, and the distribution of economic gains was - for him - the key issue defining the field of political economy. His opening remarks of the "Preface" to his Principles make this clear:

The produce of the earth - all that is derived from its surface by the united application of labour, machinery, and capital, is divided among three classes of the community; namely, the proprietor of the land, the owner of the stock or capital necessary for its cultivation, and the labourers by whose industry it is cultivated. .... To determine the laws which regulate this distribution, is the principal problem in Political Economy... (Principles, 1821, Works I, 5)

Farming thus lay at the heart of these two main problems of political economy - population and distribution - in Britain in the early nineteenth century. Despite the beginnings of industrialisation, the ongoing success

\footnotetext{
${ }^{6}$ The ways in which the population question spread into many aspects of life and ideas in the period is wonderfully evoked by Patricia James in her 1979 book about Malthus.
} 
of commerce, and the fast growth in urban centres, agriculture and its associated activities were still the largest sector of the economy. For both Ricardo and Malthus, the population problem was a given, so that the health and growth of the farming sector - which must both feed the growing population and, to a considerable extent, employ them - was critical for the well-being of the economy as a whole. If there were no possibilities of increasing output in agriculture, and if the corn laws were not repealed, Ricardo's theories predicted the end of capital investment and so stagnation in the economy. But the historical issues stretch further than this. Ricardo's theory of distribution, that is, of what determines the share of output between his three economic classes of landowners, farmers (capitalists) and labourers, lead him to argue against the political economy interests of the landowners and farmers. His theory laid the ground work for Marx's analysis of class interests and so the development of Ricardo's ideas here are not only a question for intellectual history, and a problem in the history of economics or of science more generally, but have an outcome which points to a later history of momentous political and economic events.

This paper brings together these two early $19^{\text {th }}$ century practical sciences - namely experimental farming and the political economy - and explores their connection in the making of a powerful economic theory of distribution. Agrarian and economic historians have long been aware of the importance of experimental farming in relation to the technical changes that supported the massive increase in agricultural output in that period and that prevented the kind of crises Malthus had envisaged. Economic and political historians have long been aware of the importance of the corn laws as indicative both of the class war between the agrarian elite and farm labourers and of the rural-urban power struggle as Britain underwent urbanisation. And, such struggles are understood to depend 
on the contemporary perception of how economic structures determined the distribution of gains between these groups - or as classical economists of the day would have it, the "laws of political economy" ${ }^{7}$ However, while historians of economics have stressed the importance of the political and scientific domains in their subject matter, they have not linked experimental farming with the history of political economy. As we shall see, these two practical sciences are, in this important case, intimately linked. Ricardo's theory of distribution depended on substantive elements from practical and experimental farming; and the way he developed and formalized his theory paralleled, in arithmetic form, the real experiments of farming and their reports. Thus the political arithmetic of Ricardo's farming economy and the numerical expression of the agricultural experimental results reveal both the common ground and unexpected connection between these domains.

In order to show how these two elements of experimental farming and political arithmetic came together in Ricardo's work, we first need to understand his relationship with agriculture. Previous accounts in the history of economics have rather ignored Ricardo's connections with agriculture and have been adamant that his economic theorizing was remote from empirical applicability. ${ }^{8}$ Indeed, Ricardo is often portrayed as

\footnotetext{
${ }^{7}$ See particularly Overton (1996) on agrarian and economic history, Hilton (1977) on economic and political history and Winch (1996) on the history of economics and its political dimensions.

${ }^{8}$ As an exception, his work on money and banking is generally accepted to have been based on his personal expertise. Historians of economics have written at impressive length and depth about Ricardo and his economics. The classic studies remain: Mark Blaug's (1958) book on Ricardo and his economics gives analytical depth and period context; Denis O'Brien's (1975) work on the classical economists shows how Ricardo fits into that broader tradition; and Samuel Hollander (1979) provides a (not uncontested) account of the content of Ricardo's economic ideas. Donald Winch's (1996) recent intellectual history of political economy in the period provides important background for understanding Ricardo. Ricardo's published works, and a large proportion of his letters, and other items, have been edited for publication by Piero Sraffa (1951 to 1973). (They are referred to in this paper under the title Works,
} 
the first modern economist because of the apparently "abstract" nature of his theorizing. The claim here is the opposite - that even when it looks most abstract and divorced from reality, as in his discussions of agriculture and distribution, Ricardo's reasoning makes use not only of his substantial and detailed knowledge of farming, but of his knowledge of agricultural experiments and their reporting. I therefore begin by discussing the history of Ricardo's relationship with the land.

\section{2. "You are not half a country gentleman, nor a particle of a} farmer"

This was the judgement of Ricardo's good friend, Hutches Trower, ${ }^{9}$ in November 1817. At first sight, it has a good deal of truth in it. Ricardo rarely wrote about agriculture in such a way that we would think he had any personal familiarity with the activity. This despite the fact that by 1817 he owned several large country estates with tenant farmers. The occasional comment such as "The crop is said to be a good one", ${ }^{10}$ which graces one of Ricardo's last letters before his untimely death in 1823, are not the words of a farmer, but almost those of an absentee landowner.

Ricardo, born in 1772, enjoyed an early and successful career in finance, particularly in financing the British Government's needs for cash to fight the Napoleonic Wars. His interest in economics dates from 1799, when he picked up a copy of Adam Smith's Wealth of Nations during a family stay in Bath, and he began to write pamphlets and papers on matters of finance and currency. He became a country gentleman in

followed by the volume number.) The many papers written about Ricardo are collected together in volumes edited by John Cunningham Wood (1985-94)

${ }^{9}$ Letter 235, Works, VII, p 207. Hutches Trower was one of Ricardo's great friends from his stock exchange days and the financial world of London. Trower, whose fond accusation against Ricardo furnish this section's title, also moved to the country, but unlike Ricardo became fully engaged in country life. 
1814, for, having made his money, Ricardo moved it, in part, into land, buying estates in Gloucestershire, Herefordshire and Kent, and in giving mortgages (including one on what was fast becoming a wealthy coalfield and industrial area on the edge of Manchester). From reading his correspondence, his relationship to these lands as landowner appears to have remained somewhat remote. Almost his first letter from his country estate, Gatcomb Park in Gloucestershire, in reply to advice from Sir John Sinclair, founder and President of the Board of Agriculture, predicted as much. Sinclair had glibly suggested:

When you come to London, I shall be glad to give any information you may wish for, on the subject of agriculture, the doctrines of which are now so much simplified, that in a few months you may acquire all the information necessary to become a good farmer. $\left(29^{\text {th }}\right.$ October, 1814)

In reply, Ricardo wrote:

I have not quite given up the Stock Exchange; for a few months in the year, I mean to enjoy the calm repose of a country life. Though I have a few acres of land in hand, I am not yet become a farmer. I leave the management of them wholly to others, and hardly take sufficient interest in what is going on, to make it probable that I shall ever be conversant with agricultural subjects. $\left(31^{\text {st }}\right.$ October 1814$){ }^{11}$

As good as his words, Ricardo lived partly in London, particularly during the period when the Houses of Parliament were sitting, for in 1819

\footnotetext{
${ }^{10}$ Letter from Ricardo to James Mill, Gatcomb Park, $30^{\text {th }}$ August, 1923, Works, IX.

${ }^{11}$ Letters 65 and 66, Works, VI, pp 149-50. Sinclair, one of the major Scottish landowners and agricultural activists of the day but a mere acquaintance of Ricardo, had written for some information about currency. There were contrary reactions from two of Ricardo's greatest friends. James Mill (see footnote 13 below) discouraged him from farming on profit grounds: "I shall, however, be very well pleased when I hear that you have less of it in your own farming hand. You will but lose money by that. I have some friends who have so much pleasure in losing money by farming, that it would be a pity to blame them for a little extravagance on a favourite mistress; but as you have no such concupiscence, it is loss without a return to you." (James Mill to Ricardo, November $24^{\text {th }}, 1814$, from Ford Abbey - Jeremy Bentham's home - Letter 68, Works, VI, p 169) Hutches Trower (see footnote 9 above) suggested that he take up farming and pay particular attention to the planting of trees, recommending two books which he
} 
he became an MP (for a rotten borough) of the radical-reformist persuasion, but he loved to return to his country life.

When writing from his country estate at Gatcomb, Ricardo's letters only occasionally discuss his estate. When he does so, he is lyrical in discussing its beauty and he writes of taking walks and rides into the surrounding countryside. But such country estates, as Ricardo's pictured here (Figure 1, next page), were not just a pretty house and park - they typically had their own farms. ${ }^{12}$ And while his letters show he loved the beauty of his estate and the countryside, they also suggest a certain remoteness from the estate activities and lack of "ownership" interest, for comments on his estate's farming activities are extremely rare and quickly turn into economic arguments. This letter is typical of the few comments on the farming of his estates that we find from him, written from Gatcomb Part, $9^{\text {th }}$ July, 1821to James Mill:

The country here is looking very beautiful - our haymaking is now in full vigor, and no superabundance of agricultural labour in the market. The barley and oats I am told do not look well, but the wheat is promising. The manufacturers have full employment for their men; Osman [Ricardo's son] told me yesterday that Mr. Hicks was employing his men extra hours, and of course giving them extra pay. If the labouring class, in Agriculture, and Manufactures, are doing well, we must console ourselves for the misfortunes of landlords and tenants - they form but a small proportion of the whole population, and it is no small comfort to reflect that the losses they sustain are more than made up by the prosperity of other capitalists. ${ }^{13}$

should keep by him. (Letter 102, 23 ${ }^{\text {rd }}$ July, 1815, Hutches Trower to Ricardo, Works, VI, p 237.)

${ }^{12}$ The estate included the lordship of the manor of Minchinhampton and the land amounted to more than 5000 acres.

${ }^{13}$ Ricardo's Works, IX, p 13. James Mill was his great debating companion and intellectual mentor. When they were both in London, they regularly walked together and argued about politics, economics, philosophy and much else. Ricardo's letters to his friends rarely comment on his own landscape, and hardly ever with a feeling of engagement. One special occasion was when he had just returned from a trip to Flanders, and observed both the countryside and the poverty of its folk. He was clearly happy to be home, as he wrote to Mill: "....and although I had lately seen a variety of beautiful county, my own fields and the views from them had lost none of their 


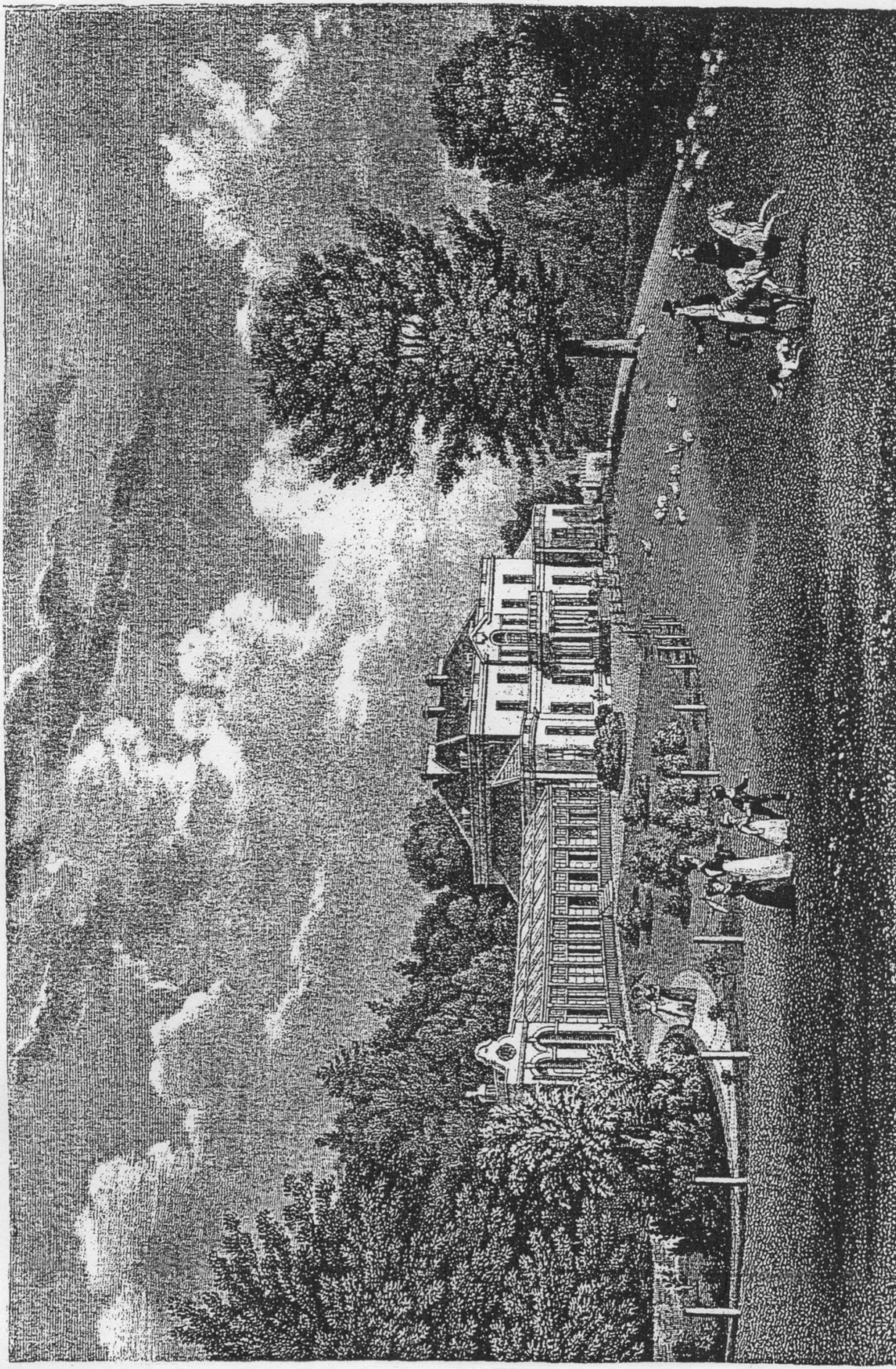


In contrast to his meagre comments on farming, there is a long and diverse correspondence for the period 1814-23 (including with Jeremy Bentham, Maria Edgeworth, James Mill, and of course Malthus and other economists of the day) which are alive with economic debate and political questions along with popular issues such as the fate of Queen Caroline during her trial. Ricardo's wealth came from finance and the political world, and he continued to be more obviously engaged with that world (via his seat in Parliament and with political debates) even while he lost his sense of engagement with that kind of wealth creation as his own wealth became tied up in the land. Somehow, Ricardo appeared divorced from the land, even while he lived on it and from it.

But, Ricardo was ever a modest man, and what his letters tell is far from the full story. He had become a large landowner and lord of the manor, and he duly became an active member of that class in all the ways that would have been expected of him. The parish of Minchinhampton, in which Gatcomb Park was situated, was both agricultural (mainly arable, with pasture for sheep) and manufacturing (woollen broadcloth was the local industry), with quite a considerable population. ${ }^{14}$ Ricardo helped in the local parish, supporting the Rector in rebuilding almshouses, starting a school and infirmary and so forth. ${ }^{15}$ He was elected Sheriff of the county of Gloucestershire for 1818, an evident sign of establishment success and local respect, though he never became a magistrate for the county. One

attractions, but on the contrary were regarded with increased interest and attachment." (Works, VII, Ricardo's letter to James Mill, p 170) Other occasions can be found, but they are few enough: eg, same volume, p 277, $12^{\text {th }}$ Aug, 1818 to Mill and again, letter $274, \mathrm{p} 305$.

${ }^{14}$ The 1801 census recorded 3,419 people in 692 houses rising to 5,114 people in 1,116 houses in the 1831 census. This and other information about Ricardo's country estate and the local industry has been gleaned from Herbert's (1976) Victoria County History of Gloucestershire. Vol XI: The Stroud Valleys.

${ }^{15}$ For example, he started a local school in Minchinhampton in 1816 on the Lancastrian system which took both boys and girls, totalling 250 pupils in 1818 (see Herbert, 1976, p 206). 
of his biographers suggests it was perhaps because he was not a member of the aristocratic land-owning Whig elite. ${ }^{16}$

Even so, this wider picture of Ricardo as a member of the landed gentry is still incomplete, for despite the way he wrote about Gatcomb Park, he was by no means divorced from the agricultural realities and debates of his day. His interest in political economy had begun to deepen and to widen from matters of currency, bullion and trade to those of agricultural and industrial economy as early as 1811, three years before he became a landowner. ${ }^{17}$ In fact, as his letters show, he became interested in questions of prices, agricultural scarcity and thence issues of agricultural growth and questions of rent and profit so that by 1814 he was actively writing and lobbying against the corn laws. These laws, had long restricted the import of corn, and, as Ricardo believed, kept the price unreasonably high to the benefit of the landlord and the detriment of the labourer. We see from his letters, that in September 1814 he had been reading the House of Lords' Report into the Corn Laws (or more correctly into the ".... State of the Growth, Commerce and Consumption of Grain...") and briefly discussed the "Evidence" section of that report with Malthus. Ricardo complained that the report "discloses some important facts, but how ignorant the persons giving evidence appear to be of the subject [of political economy] as a matter of science". ${ }^{18}$ From the point at which he entered Parliament in 1819, Ricardo gained a further wealth of knowledge of the agricultural experience of Britain of his day particularly as he sat on

\footnotetext{
${ }^{16}$ This is from Weatherall's (1976) biography, a broad-ranging, family, account. Another useful biography, which focusses attention on Ricardo's Jewish background is by Henderson with Davis (1997).

${ }^{17}$ These interests and their dating can be seen quite clearly from the relevant Works, III and $I V$ and in his letters, Volumes VI-IX.

${ }^{18}$ Malthus found the report to be on his side "It [the report] contains as you observe some very curious information. The evidence is a little suspicious, though it is a good deal such as I expected from [my] Theory". Letters 58 and 59, Ricardo to Malthus $30^{\text {th }}$ August, 1814 and Malthus to Ricardo, $11^{\text {th }}$ September, 1814 Works, VI, pp 130 and 132.
} 
the Select Committee investigating agricultural distress in 1821 and 1822. And, throughout the period from 1815 , he received letters from his land agent, Edward Wakefield, informing him of his duties as a good landlord, his tenant farmers' problems, the state of the market for land, the prices of produce, and the difficulty of finding reliable new tenants. ${ }^{19}$

Ricardo must have also been familiar with the experimental farming activities of his day for no intelligent and engaged political economist moving in both the political and landed gentry circles, as he did, could have remained ignorant of them. He knew of the agricultural activities of the Whig landowners as well as of the new system of agriculture. For example, he refers in one letter to the annual agricultural meetings (known as a "sheep-shearing") of 1821 at Holkham Hall as "Mr Coke's annual feast" where the latest experimental results were reported, new breeds shown and visitors were escorted around the experimental plots. ${ }^{20}$ He was familiar with the various schemes of the time for agricultural improvement which had grown out of these experimental farming activities and in his letters he often pointed to the importance of agricultural improvement both as a necessary requirement for growth and as an obvious part of the experience of his day. His writings show that he was familiar with the main technical improvements in farming of the period, although he does not seem to have been directly a participant in experimental activities himself. ${ }^{21}$

${ }^{19}$ These letters from Edward Wakefield can be found at the University Library in Cambridge. Unfortunately, Ricardo's letters in reply are not part of the collection. 20 See Ricardo's letter to Mill of $28^{\text {th }}$ August, 1821 (Works, IX, p45-6). In fact, this was the last of these great events, which, though they had been going for over 40 years, had become large scale only in the early $19^{\text {th }}$ century. For information on the these meetings, see Goddard (1989), p 377-8.

${ }^{21}$ I have found no evidence that Ricardo's tenants were involved in agricultural experiments, but certainly Wakefield was concerned about employing best practice farming. And, the erstwhile owner of Gatcomb Park, Edward Sheppard, father of the immediate previous owner Philip Sheppard, had experimented in sheep breeding on an estate at Avening, the next door parish to Minchinhampton, a mere few miles away from Gatcomb and which had previously been held under the same ownership. 
But there is another, much more obvious reason that we appreciate his familiarity with the agricultural improvements of his day and the experimental element involved. The writing in his Principles of Political Economy and Taxation is very formal, but he very occasionally moves from neutrality to the $1^{\text {st }}$ person singular voice - and he does so precisely at the point when he discusses the possibility of increasing agricultural output through introducing new technology and changing farming

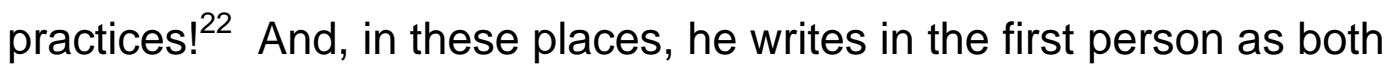
capital investor or farmer (making profits) and as landlord (collecting rents) - the two roles which he has been careful to keep separate in the rest of this chapter. This is indirect evidence, but surely pertinent and all too easily overlooked - so easily that I will need to point it out when we reach that event in section 3 .

It is perhaps worth emphasizing here, so that confusion does not arise later, that Ricardo was not a Whig, but a more radical reformer. He thought seriously about constitutional reform and widening the suffrage; and, in his speeches in Parliament, his writings about agricultural issues, and in framing his policy positions, Ricardo clearly empathized more with the problems of the labourer and farmer than with those of the landlord. We see this in the letter to Mill quoted earlier and it is an important point to note in understanding Ricardo's thinking about the economic world, for, although he was a landlord, his theory of political economy had the interests of the landlord at odds with those of the labourer and farmer. His sympathy with the labourers' position was one reason behind his consistent opposition to the corn laws and his unsympathetic response to petitions from farmers and landowners on agricultural distress. ${ }^{23}$

\footnotetext{
${ }^{22}$ There is another obvious case later where he is discussing investment along similar lines, and he writes as the farmer-investor in his chapter "On Machinery".

${ }^{23}$ See for example his remarks on such a petition in Works, VI, p47. However, it was not the case that he let his sympathy with the plight of the labourers interfere with his
} 
In sum, the evidence suggests that far from being a wealthy absentee landowner uninterested in agriculture as he appears at first sight, Ricardo was almost certainly very knowledgeable and engaged with farming problems. Let me turn now to Ricardo's discussion of agriculture in his Principles, and in particular put those into perspective by placing them against some experimental farming reports of technical changes and the agricultural debates of his day. My purpose is to show in more detail how Ricardo used his knowledge of farming, and how contemporary agricultural experiences were integrated with his theories in the form of arithmetical experiments that in turn helped him develop his theory of distribution.

\section{Farm Accounting and Questions of Distribution}

Ricardo's theorizing about investment, growth and distribution in the economy began with questions about the agricultural economy, and though most works in political economy of that time were expressed in words, Ricardo also used numbers, and in an unusual way, to help him argue his case. His first published theorizing on these general questions appeared in his 1815 pamphlet against the corn laws, where he used a couple of large tables to argue and demonstrate his points. These tables were replaced by numbers scattered through the relevant chapters of his main Principles book in 1817 . In some places, particularly consistently and extensively in his discussion of agriculture, these numbers are formed into arithmetical cases or examples for reasoning with. Historians of economics have not paid a great deal of attention to these numbers, ${ }^{24}$ and because Ricardo is considered the first abstract reasoner, these numbers

views on the Poor Law. He was certainly a charitable man, but decried the incentive systems inherent in the Poor Law.

${ }^{24}$ With the main exceptions of Barkai, 1959, and Gootzeit, 1975. 
have not been seen as reflecting "evidence" about the agricultural economy of his day. ${ }^{25}$

In this part of the paper, I suggest that if we take these numbers seriously, we will find that they connect directly to the agricultural problems of Ricardo's day. Not only do we find that his numbers are rather representative of the agricultural numbers of the period, and that his constructed examples expressed the farming changes and agricultural difficulties perceived at that time, but that these examples also mirrored the experimental farming literature in content and in form of accounts. His political economy theorizing thus discussed real problems of agriculture and they employed real, down to earth, numbers. However, as we shall also see, these numerical accountings were not just illustrations of contemporary conditions, but thinking tools - numerical experiments rather than real agricultural experiments - upon which Ricardo built his theory of distribution between the classes. The extended use of such thinking tools was generic to Ricardo, and, although the method was partly taken up by others during the period, its importance lies not in changing the format of economic thinking to become empirical rather than theoretical, but paradoxically - in providing a vehicle to theorize more effectively.

\section{3.i The 1815 Essay and Table}

Let me begin this account with Ricardo's 1815 pamphlet known as his Essay on Profits, fully titled "An Essay on The Influence of a low Price of Corn on the Profits of Stock". This was an essay on one of the hottest political issues of the day. Corn prices had been extremely high from 1795 due to poor harvests and the Napoleonic Wars which disrupted

\footnotetext{
${ }^{25}$ But, while Ricardo's ways of arguing were unusual, the arguments above suggest that it is by no means obvious that he was less well informed or less well able to judge the agricultural realities than his friend and rival, Malthus, who for many years had
} 
imports. Indeed, prices had been high enough to cause food riots, changes in the poor law system and the extension of arable farming into newly enclosed areas so as to increase domestic production. At their peak in 1812, prices were around three times the late $18^{\text {th }}$ century level. Somewhat suddenly, there had been a fall in the price of corn due to a bumper harvest in 1813 and, after peace in 1814, prices fell further. They were still around double the pre-war level, but just below the level at which tariff protection came in. ${ }^{26}$ So corn prices had been on the political agenda for some time, but with falling prices, rents were threatened, raising both farming and landowning interests to demand further protection under the corn laws. ${ }^{27}$ The labouring class was not in favour of such restrictions which they regarded as keeping the price of bread at a high level, and Ricardo sided with them. He commented on the riots against the laws that occurred in London in March 1815 in one of his many letters to Malthus (Works, vol VI, letter $77, \mathrm{p} 180) .{ }^{28}$ In that same year of 1815, Ricardo's new country parish of Minchinhampton found the cost of poor relief had risen to $£ 2000$ and 230 people were on permanent out-door relief. ${ }^{29}$ Parliament investigated the corn laws in 1814, but the farming "interests" (the landlords and tenant farmers) won the day of

been the parson of a rural parish (before becoming the first professor of political economy in England).

${ }^{26}$ See D.P. O'Brien, 1981, pp 359-60 on the discussion of high prices and their effects, Dorfman 1989 for the following fall. The full series of corn (small grains) prices can be found in Mitchell (1971), p488-9.

${ }^{27}$ Rents per acre, which had been rising steadily since the 1790 s, levelled off around 1815, but at double their pre-war level. See Turner et al, 1997.

${ }^{28}$ These riots were not only urban affairs. The machine burnings and the burning down of corn barns, both well-known to historians, were a feature of the period:- Trower wrote to Ricardo about a neighbour's barn-burning experience in July 1816 (Works, VII, p 45).

${ }^{29}$ This was against a number of households which probably lay between 700 and 1000 households; see Herbert, 1976, p 201 and 188, who also states that "from 1814, the poor in the house were farmed" ( $p$ 201), which I take to mean were set to work on farms within the parish. 
course and the laws remained. ${ }^{30}$

Ricardo argued against the corn laws in his 1815 essay by combining Malthus' definition of rent with his own theory of profits. Ricardo's argument was primarily concerned with profits, and with the danger that these might fall so low as to cause stagnation in the economy. His argument purposely assumed that there was no technical change in agriculture, an assumption made to highlight the dangers of falling profit levels since technical change was one of the main means by which capital would continue to find profitable investments. This essay also marked the start of Ricardo's arguments about the relative distribution of returns to the landlord and the farmer (capital holder) from capital investment in agriculture and from extending agriculture onto other lands as a way of increasing produce to feed the rising population. As yet, the position of the labouring class in the distribution analysis of the table was not clear, although his letters of the period show that he was fast working out the theory of distribution that appeared more fully in his Principles of 1817.

Blaug $(1958$, p 6) correctly argues that "Ricardo's theoretical system emerged directly and spontaneously out of the great corn laws debate of 1814-16." But it was Ricardo's familiarity with the kind of "evidence" given in this debate that was critical for the development of his theories and his way of arguing. ${ }^{31}$ As we have already noted from an exchange of notes between Malthus and Ricardo, Ricardo was familiar with the presentation of the "Evidence" section of the 1814 parliamentary investigation into the corn laws. This "Evidence" consisted of the reports of those who came to give evidence to the committee and reports of their

\footnotetext{
${ }^{30}$ Though there was some alteration: the 1815 act abolished the sliding scale of duties on imports and replaced it with import prohibition when the price was below 80sh, with free imports over that price.

${ }^{31}$ Ramana (1957, p 198) has, like Blaug, argued that this pamphlet by Ricardo (along with contemporary ones by Malthus, Torrens and West) were the direct outcome of the
} 
cross examination by committee members. (The second witness was in fact Edward Wakefield, who in 1815 became Ricardo's land agent). The range of statements vary in form; there were personal descriptions, price averages, and a wealth of arithmetic farm accounting statements presented by individual farmers and landlords. (Just to mark the nature of this "evidence", I should add that the long set of tables of data that appeared separately attached to the report, were not called "evidence" but "accounts".) These individual farm accountings are particularly relevant for Ricardo, who argued his major points, and demonstrated the proof of these arguments, by using an elaborate double table of hypothetical farm accounts.

Ricardo's pamphlet on the corn laws appeared along with several others, but his showed the most sophisticated use of numbers and tables. By comparison, Edward West's pamphlet on rent, which appeared just before Ricardo's, made some of the same points and used numerical arguments in a somewhat similar way to Ricardo, yet in no way matched the extended table of Ricardo's 1815 pamphlet, nor the continuity and complexity of the numerical accounts he produced in his Principles. Malthus' 1814 pamphlet on the corn laws and 1815 pamphlet on rent contained no use of numbers, tables or farm accounts (in contrast to his earlier, but very much simpler, numerical formulation of his laws of population). Robert Torrens's pamphlet, which appeared at the same time as Ricardo's, used numbers to a very limited extent. Both Torrens and Malthus began to use Ricardo's more sophisticated numerical examples in their later writings. In this respect, his work proved something of an exemplar for other political economists of the day.

Ricardo's 1815 essay marked an important half-way stage in two respects: in his theory and in his reasoning. First, he had allowed for no 
technical change in his reasoning, an assumption he gave up in his book as being counter to the agricultural realities of his day. Second, he developed these accounting experiments in a way that allowed him to develop a full theory of distribution and show the outcome for all three factors, landlords, capital holders and labourers.

\section{3.ii The Principles and Experimental Accounts}

Ricardo's investigations proceeded further in his more thorough and well known Principles of Political Economy and Taxation (in three editions in his life time: 1817, 1819 and 1821). Here, he abandoned such (comparatively for his time) large tables and used smaller numerical examples in stages, each illustrating and demonstrating a different part of the argument as relevant for the particular topic argued in his chapters. These numerical examples or farming accounts appear in different forms, sometimes running through the lines of text, sometimes as a set of mini farm accounts, and sometimes in footnotes. This is also how the farming experiments were reported in the period - sometimes running through the text, and sometimes as a set of farm accounts. I shall show a couple of these documents in their original formats so that we can see how Ricardo's political economy used the same kinds of reports and accountings that appeared in agricultural experimental work.

Recall that for Ricardo, political economy is defined as being about distribution, and he had set for himself the challenge of understanding its determining laws. So, although Ricardo begins his Principles with a standard classical opening chapter about labour as the source of value, he then moves immediately to the question of rent and this drives his account through the following pages until his theory of distribution is laid out a few chapters further on. Rent is defined by Ricardo as: "that portion 
of the produce of the earth which is paid to the landlord for the use of the original and indestructible powers of the soil. It is often, however, confounded with the interest and profit of capital, and in popular language, the term is applied to whatever is annually paid by the farmer to his landlord." $(1821,67 / 33){ }^{32}$ But the definition does not motivate much on its own. Ricardo wanted to make his theory of rent absolutely clear: how rent arose; how the amounts were determined; how it was affected by agricultural investment; and most importantly, how it featured in the distribution of income. But a static account would not do. The economy was in a period of rapid change and the classical concerns of the early $19^{\text {th }}$ century were with growth as much as they were about value. Ricardo needed to demonstrate how his theory of distribution applied over time and how changes in each element affected the distribution to the others. His theory of rent therefore had to be supple enough to explain both the distribution and how it changed.

While fashioning a theory of distribution was Ricardo's main aim, his Principles needs must address the general problem of population growth, and the necessity of growing more food at prices labourers could afford. This is generally understood as Malthus' problem, but it was perceived as the main agricultural/rural problem of his day, sometimes disguised as the related issue of poverty due to lack of work as population increased. So, all of Ricardo's accounts discussed here are in fact also motivated by various aspects of the population problem. As we shall see however, his solutions suggest that this food production/labour employment problem could be attacked as various sub-problems in different ways.

In the first substantial arithmetic account used to discuss the

\footnotetext{
${ }^{32}$ In this section, both page numbers refer to the 1821 edition of the Principles, first to Sraffa's edition (Works, I), and secondly to the more accessible Everyman 1973 edition.
} 
problem of feeding the growing population in his Principles, Ricardo proposes that farmers will bring in additional (more marginal) land into cultivation and he uses this to show that under such circumstances, rent will arise. Here is his text quoted to show the running numerical example:

\section{Document 1:}

Thus suppose land - No. 1, 2, 3 [of three different qualities] - to yield, with an equal employment of capital and labour, a net produce [after wages are paid] of 100, 90, and 80 quarters of corn. In a new country, where there is an abundance of fertile land compared with the population, and where therefore it is only necessary to cultivate No. 1, the whole net produce will belong to the cultivator, and will be the profits of the stock which he advances. As soon as population had so far increased as to make it necessary to cultivate No. 2, from which ninety quarters only can be obtained after supporting the labourers, rent would commence on No. 1; for either there must be two rates of profit on agricultural capital, or ten quarters, or the value of ten quarters must be withdrawn from the produce of No. 1 for some other purpose. Whether the proprietor of the land, or any other person, cultivated No. 1, these ten quarters would equally constitute rent; for the cultivator of No. 2 would get the same result with his capital whether he cultivated No. 1, paying ten quarters for the rent, or continued to cultivate No. 2, paying no rent. In the same manner it might be shown that when No. 3 is brought into cultivation, the rent of No. 2 must be ten quarters, or the value of ten quarters, whilst the rent of No. 1 would rise to twenty quarters; for the cultivator of No. 3 would have the same profits whether he paid twenty quarters for the rent of No. 1, ten quarters for the rent of No. 2, or cultivated No. 3 free of all rent. $(1821,70-71 / 35-6)^{33}$

Although the example of bringing new land into cultivation might seem contrived, this was far from the case. Despite the island constraint and relatively high population density for the period, there was an ongoing process of enclosure of common pasture (or "wastes") and a consequent increase in arable acreage during this period. These were

\footnotetext{
${ }^{33}$ Later in the book, Ricardo develops this example by taking gross amounts of output and looking at the effect adding taxes and tithes.
} 
the well-known realities of the day. ${ }^{34}$ Ricardo's example was designed not only to outline the process of increasing output, but also to show how rent arose and explain its level by connecting it with the fact that the same amount of labour and capital produced less output on the poorer quality of land than on the better. This argumentation, and the arithmetic outcomes, depended not only on Ricardo's definition of rent, but upon two classical economic assumptions, namely, the tendency of profits to equalize and that the profit rate is determined on the least productive land. The determination of rents is the difference in net produce (after wages are paid) between the more and less productive land.

A second alternative - and associated numerical example - to solve the need for increased food by a growing population was to increase capital inputs on the same quality land, again another well-observed feature of Ricardo's day. ${ }^{35}$ In his third arithmetic account, Ricardo investigates technical change in agriculture as a way of increasing food output. He assumes that all improvements in agriculture are labour saving and, because of the labour theory of value, they lead to a fall in the price of the good produced:

"If they did not occasion a fall in the price of raw produce they would not be improvements; for it is the essential quality of an

\footnotetext{
${ }^{34}$ As shown, for example, in the evidence to the Lords Report in 1814. See Allen, 1994 for a modern assessment and Mingay 1997 for a discussion of enclosure during the period.

${ }^{35}$ In this second numerical example, he assumes that successive capital investments will produce declining increases in output, but since profits must always be equal, the difference between levels of profits on the segments of capital will be the amount of rent paid. It is not only rent which rises under these circumstances, but the relative price of agricultural produce. This assumption relates to the classical economics "labour theory of value" which holds that it is labour alone which creates value, and that there is a direct relationship between labour input and value. If less labour has to be used to produce a commodity, the value of that commodity will, ceteris paribus, fall relative to others and vice versa. Reich (1980) finds contemporary evidence to support Ricardo's belief in declining returns to agricultural investment, despite the period of improvement. Blaug argues that this classical assumption was widely believed at the time to be correct (Blaug, 1956, pp 159-60).
} 
improvement to diminish the quantity of labour before required to produce a commodity; and this diminution cannot take place without a fall of its [the commodity's] price or relative value." (1821, 80/42). What kinds of technical changes is Ricardo considering here?

Another numerical account (document 2) answers this. This most interesting passage clearly shows that Ricardo was familiar with at least two of the main results of the experimental farming movement: the importance of manure, and the role of root crops (associated in particular with the work of "Turnip" Townshend in the earlier $18^{\text {th }}$ century) which introduced the "Norfolk" crop rotation. Crop rotation was still very much a part of the experimental farming of Ricardo's day. For example, Rudge, in his 1813 account of the agriculture of Gloucestershire (wherein Gatcomb Park lay) for the County studies for the Board of Agriculture provided a long accounting of alternative crop rotations in both physical and monetary terms. 


\section{Document 2:}

The improvements which increase the productive powers of the land, are such as the more skilful rotation of crops, or the better choice of manure. These improvements absolutely enable us to obtain the same produce from a smaller quantity of land. If, by the introduction of a course of turnips, I can feed my sheep besides raising my corn, the land on which the sheep were before fed becomes unnecessary, and the same quantity of raw produce is raised by the employment of a less quantity of land. If I discover a manure which will enable me to make a piece of land produce 20 per cent. more corn, I may withdraw at least a portion of my capital from the most unproductive part of my farm. ..... If, for example, the successive portions of capital [invested in the same land] yielded 100, 90, 80, 70; whilst I employed these four portions, my rent would be 60 , or the difference between

$\begin{array}{rlr}70 \text { and } 100 & =30 \\ 70 \text { and } 90 & =20 \quad \text { whilst the produce would be } 340 \quad & 100 \\ 70 \text { and } 80= & 10 \\ & & 90 \\ 60 & & 70 \\ 340\end{array}$

If, instead of $100,90,80,70$, the produce should be increased [through "improvement" such as manure] to $125,115,105,95$, the rent would still be 60 , or the difference between

95 and $125=30$

125

95 and $115=20$

whilst the produce would be

115

95 and $105=10$

increased to 440

105

95

60

$\overline{440}$

$(1821,80-81 / 42-43)^{36}$

This quote is also the passage which shows us Ricardo thinking as

${ }^{36}$ From this, Ricardo argued that after technical change, the original output of 340 can be produced with just three units of capital, so that if the population was already fully provided for, the final unit of capital could be withdrawn bringing net produce back to 345 , but also reducing rent by 30 . Thus, in this account, technical change can affect both the amount of capital (that needs to be invested in agriculture) and rent. 
a farmer - for it is at this point that he becomes a farmer in the first person, discussing the possibility of himself introducing a "course of turnips" (into the field rotation of crops), or of himself discovering a better, a more "invigorating manure" ( $p$ 81/43) to his fields. This is a rare use of the informal first person singular in his text, which usually remains strictly formal. Further we can see that he so far enters into the issues of agricultural improvement that he speaks of himself as a farmer being enabled to pay lower rent - even though of course it would be a loss of income which he would in real life have to bear as a landlord!

Ricardo's discussion and numerical account above are given in the form of an arithmetical account of a hypothetical experiment. And it is a complicated experiment: In the first stage there is a variation in capital input and we see the variation in output as the "treatment" is varied. In the second stage, there is the application of manure (or equivalent improvement) and this creates a further set of output data using the same variations in capital inputs - a kind of double experiment. This numerical experiment can be neatly compared with an actual field trial experiment on the application of manure reported in a weekly farmers' journal in 1817 by someone from Tetbury, less than 10 miles from Ricardo's country estate (see document 3). 


\section{Document 3:}

From The Farmer's Journal ${ }^{37}$

Letter from A.L.

Tetbury, April 26, 1817

"Method of Employing the Agricultural Poor"

Several portions of land in a large field, in equal divisions, were marked out, and all planted with potatoes of the same kind, the same soil, the cultivation the same in every respect, except that in one division no manure was put on the ground before planting with potatoes. All the other divisions were manured with different quantities of manure, progressively increasing from ten cartloads per acre up to forty, which was the highest quantity put on any division; the consequence was, that the crop without any manure, cost $£ 6$. per acre, including rent, \&c. and produced 24 sacks per acre, which sold, at 5 s per sack, for exactly $£ 6$.; and, therefore, left no profit whatever for the grower, or interest for his capital employed. The other divisions produced from two and a half to four sacks additional for every additional cart-load of manure (which was chiefly sweepings of the streets of a town, and cost 5 s the load when on the ground); and the highest, manured at 40 load of manure to the acre, yielded 160 sacks of Potatoes per acre, which at 5 s per sack is $£ 40$. or $£ 150$. per cent profit.

This exemplary experiment is reported in the same form as some of Ricardo's numerical experiment accounts, where the reporting runs through the text. But it can easily be reformed to take the kind of appearance that we see in Ricardo's tables above or in other farming experiments reported in that same journal in the period (see document 4).

37 Evans and Ruffy's Farmers' Journal and Agricultural Advertizer, more generally known as The Farmers' Journal, was a weekly paper, the first agricultural newspaper, and lasted from 1807 until its taking over in 1832 (see Goddard, 1983). It was the most widely circulated agricultural journal of its day, and was known for its strong protectionist line. I don't know if Ricardo read the journal, but its readers were certainly familiar with him and his views and felt entitled to take issue with them. (The Editor was also vehemently critical of Ricardo, but indeed of almost everyone else as well!) Ricardo's pronouncements on currency and the corn laws (for example) were reported in the paper and argued over there. On one occasion: January $17^{\text {th }}, 1820$, a correspondent from Bedfordshire outlined a set of hypothetical farm accounts assessing the impact of the corn laws in a letter explicitly addressed as "Questions to Mr Ricardo". 


\section{Document 4:}

Mr A.L.'s Experiment 1817

Total cost (including rent) of potato cultivation per acre $=£ 6.0 .0$

Production per acre 24 sacks; selling at 5sh each: total $\quad=£ 6.0 .0$

Profit and interest on capital invested

$\overline{£ 0.0 .0}$

Experimental addition of manure at 5 sh per load

Minimum treatment of 10 cartloads per acre cost $\quad=£ 2.10 .0$

Maximum treatment of 40 cartloads per acre cost $\quad=£ 10.0 .0$

Plus original cultivation costs apart from manuring $\quad=£ 6.0 .0$

Total costs

$=£ 16.0 .0$

Production per acre 160 sacks; selling at 5sh each: total $\quad=£ 40.0 .0$

Profit and interest on capital is $150 \%(24 / 16) \quad \overline{=£ 24.0 .0}$

Ricardo's next numerical account considers alternative

improvements to agriculture which we know also to be part of the experimental farming tradition, namely those resulting from "Improvements in agricultural implements, such as the plough and the thrashing machine, economy in the use of horses employed in husbandry, and a better knowledge of the veterinary art, are of this nature."(1821, 82/44).

The fifth alternative that Ricardo proposes is to add labour to the field in units of 10 men at a time. Ricardo assumes that with successive doses of extra labour, output will increase at a declining rate (that is, declining returns to the input, as had earlier been the case with extra doses of capital investment). Here, I again provide the direct and full quote - which originally appears as a footnote at the very end of his chapter "On Rent" (see document 5). 


\section{Document 5:}

To make this obvious, and to show the degrees in which corn and money rent will vary, let us suppose that the labour of ten men will, on land of a certain quality, obtain 180 quarters of wheat, and its value to be $£ 4$ per quarter, or $£ 720$; and that the labour of ten additional men will, on the same or any other land, produce only 170 quarters in addition; wheat would rise from $£ 4$ to $£ 4$ 4s. 8d. for 170: 180 : : $£ 4$ : $£ 4$ 4s. 8d; or, as in the production of 170 quarters, the labour of 10 men is necessary in one case, and only of 9.44 in the other, the rise would be as 9.44 to 10 , or as $£ 4$ to $£ 4$ 4s. 8d. If 10 men be further employed, and the return be

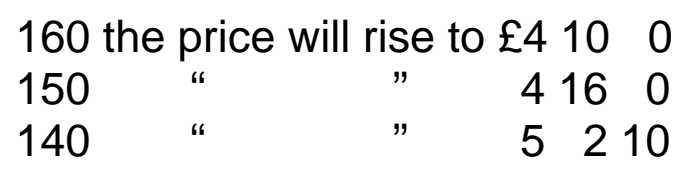

Now, if no rent was paid for the land which yielded 180 quarters, when corn was at $£ 4$ per quarter, the value of 10 quarters would be paid as rent when only 170 could be procured, which at $£ 44$ s. 8d. would be $£ 427 \mathrm{~s}$. $6 d$.

20 quarters when 160 were produced, which at $£ 4100$ would be $£ 9000$ 30 quarters " 150 " " 4160 " 414400 40 quarters " $140 \quad$ " " 5210 " 5205134

$\begin{array}{clll} & 100 & & 100 \\ \text { Corn rent would increase in } & 200 & \text { and money rent in the } & 212 \\ \text { the proportion of } & 300 \text { proportion of } & 340 \\ 400 & & 485\end{array}$

The rationale or motivation for Ricardo's arithmetic experiment of adding labourers 10 at a time to a field is not so clear as the other examples. As a footnote, it offers itself as an explanation of an otherwise cryptic statement about the nature of rent under these circumstances of increasing labour input "First, he [the landlord] obtains a greater share, 
and, secondly, the commodity in which he is paid is of greater value." ( $p$ 45) As we can see, from the arithmetic account of the experiment, by increasing labour, rent increases in terms of quarters of corn, but in each round the price of a quarter rises, and the landlord gets a double benefit: he gets more corn and the value of each quarter rises. ${ }^{38}$

But, even though this was but a final footnote to the chapter on rent, the example soon becomes very much more important than it first appears. For the first time, prices - of corn and rent in monetary form have appeared in the example. (And, as an aside, I note that the prices quoted here are within the normal range of corn prices for $1815-23$. $£ 4$ or 80 shillings being reasonable; $£ 5$ or 100 shilling being high $\{1817$ was an exceptionally high year being around 120 shillings or $£ 6\}$.) And, although the account seems to be about a minor point on rent, in the context of the other accounts earlier in the chapter, the addition of more labourers to the field can most reasonably be interpreted as another solution to the population/food problem.

But certainly much more important for the text as a whole, is that the example forms the basis for two further extensions to the arithmetical account. The first is in the chapter "On Wages", the only worked out numerical example in that chapter, where Ricardo extends the numerical account to explore the effect on wages of the increase in the price of corn as more labour is used on the same land. In the second case, in the

${ }^{38}$ This might be clearer from reformulating Ricardo's example into a table:

\begin{tabular}{|l|l|l|l|l|l|l|}
\hline $\begin{array}{l}\text { Land } \\
\text { Quality }\end{array}$ & Labour & $\begin{array}{l}\text { Output } \\
\text { Qts }\end{array}$ & $\begin{array}{l}\text { Price per } \\
\text { Qtr }\end{array}$ & Rent Qts & Money & $\begin{array}{l}\text { Money } \\
\text { Index }\end{array}$ \\
\hline & & & & & & \\
\hline 1 & 10 & 180 & $£ 4$ & 0 & 0 & 0 \\
\hline 1 & +10 & +170 & $£ 4.4 .8$ & 10 & $£ 42.7 .6$ & 100 \\
\hline 1 & +10 & +160 & $£ 4.10 .0$ & 20 & $£ 90.0 .0$ & 212 \\
\hline 1 & +10 & +150 & $£ 1.16 .0$ & 30 & $£ 144.0 .0$ & 340 \\
\hline 1 & +10 & +140 & $£ 5.2 .10$ & 40 & $£ 205.13 .4$ & 485 \\
\hline
\end{tabular}


chapter "On Profits", the account forms the basis for a worked example (another is used later in the chapter) exploring the effect on farmers' profits of increasing labour input. In doing so, Ricardo uses the numerical accounting to show how the whole product is shared between the three classes, namely, farmer, landlord and labourers. ${ }^{39}$ This final account is therefore extremely important. It constitutes the medium in which his theorizing about distribution - and his laws of distribution - are demonstrated finally and in full. ${ }^{40}$ I provide here Ricardo's accounting for this case $(1821,116 / 68)$ (see document 6$)$.

\footnotetext{
${ }^{39}$ Reich (1980) attempts to analyse how far the share of rent has risen during Ricardo's life and to look at the empirical basis for Ricardo's arguments about rent in corn and rent in money. I merely note here that Ricardo assumes that wages consist of a corn amount and a money wage amount and uses numbers which are close to the prices of corn and money wages paid in his time.

${ }^{40}$ See Barkai, 1959, on the difficulties of interpreting this numerical example in consistent terms.
} 
Document 6:

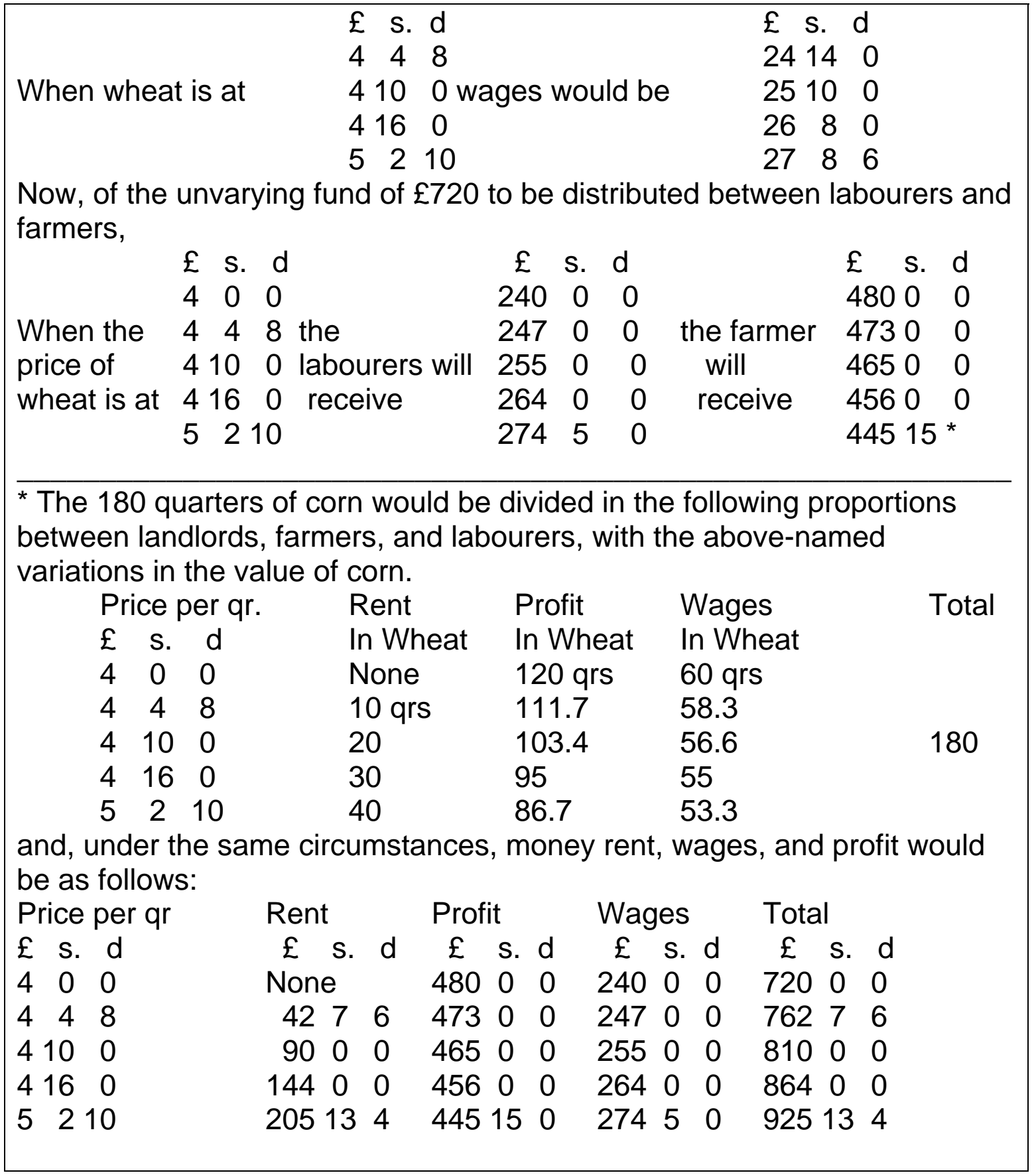

Following his final arithmetical experiment demonstrating the distribution of the product to the three classes, Ricardo then also shows that if population increases to the point where the whole of the distribution goes only to labourers and landlord, the farmers' profits fall to zero as the 
share to landlords in rent increases. Whereas Malthus feared population growth because of the vice and misery that accompanied it, for Ricardo, as he had showed in 1815, the danger was that, in the absence of any technical change, profits would fall so far that there would be no investment, and so stagnation rather than growth in the economy.

In the broader context of the overall argument in Ricardo's Principles, the example of adding labourers to the same fields initially looks as if he was just covering the case for completeness of his argument. But when he continues with this accounting, and uses it to build up his theory of distribution between the three economic classes defined in Ricardian classical economics: landlords, farmers/capitalists and labourers, we become aware that it is a very important case indeed. Nevertheless, the case still is a very particular one - and even a peculiar one - for it does not seem to fit into the traditional range of agricultural experiment and agricultural improvements, of adding manure or of adding machinery, which he has already discussed. In his initial footnote formulation of the example, Ricardo makes no attempt to relate the idea of adding so many more men to the field to the agricultural problems of his day, so that the continuation of the example into his theory of rent and wages make the whole agricultural economy portrayed in this theory of distribution seem particularly artificial.

But it turns out that this example, of adding more and more men to a field, is not at all a hypothetical case but rather an empirical case of the day. Adding labourers to fields was tried by a number of experimenting farmers and there was also clearly a contemporary policy context in which Ricardo's accounting of this example is an important one. These two contexts suggest why Ricardo included the example in the first place, and why it continued to be the relevant case for exploring those further issues of distribution. These two contemporary contexts, those of agricultural 
experiment and political economy, can be found raised together in the "spade husbandry" debate to which I now turn.

\section{$4 \quad$ The Spade Husbandry debate}

\section{4.i The political dimensions of the debate}

The spade husbandry debate engaged with both the experimental farming communities of the day and contemporary worries about the condition of the labouring classes, the distress caused by their lack of employment in the late 1810 s, due to the sudden fall in prices of arable crops which induced farmers to lay off labourers (compounded in some localities due to industrialization), and the burden on the Parish-based poor law of unemployed labourers as population grew.

This debate contains a number of elements. First, the debate is concerned with a particular kind of cultivation which employs many labourers. The questions are concerned with both yields per acre and per man, and in particular with the relative profitability of labour intensive versus capital intensive methods of cultivation. Proponents argued that employing labour in spade husbandry constituted a different technology, that adopting it would increase yields so much that product prices could fall and labour could be paid more. Opponents argued that increased labour usage must increase costs and therefore prices, despite a possible rise in yield per acre. So, in an immediate sense, the efficacy of spade husbandry was an experimental question of the day - open to argument and to experimental test. There were also contemporary arguments about exactly what technology was involved here - but it implies either spade digging, or manual labour with other tools including some use of horses (eg "breast ploughing") which makes the term "spade husbandry" a generic technology rather than descriptive of any one particular technique. 
Second, the spade-husbandry debate overlaps with the discussions of "garden husbandry". Under this conception, spade husbandry offered a positive vision of a return to small-holder farming methods based on labour, whether the method was used on a large or small holding of land (and both situations were discussed). This was in contrast to the notion of capitalist agriculture, a reality of large scale, landowner-tenant farmer using more capital intensive methods (ie, plough teams). This gives the debate clear political overtones.

Third, the debate sometimes included explicit discussion of the duty of the farmer/landowner to support the poor of the parish. Spade husbandry appeared to offer landowners the possibility of providing profitable (to the landowner) employment to local unemployed labourers as an alternative to supporting those same people via the local poor law. Thus, this was a matter for debate in the local political economy.

Fourth, spade husbandry sometimes became part of a make-work scheme. For a visionary utopian scheme, there was Robert Owen's 1819 proposal for a model community using spade husbandry as part of a garden husbandry utopia. A capitalistic agriculture alternative was found in Sir John Sinclair's proposed in 1819 to set up a joint stock company for a big investment in spade husbandry on marginal land. This widely publicized scheme was designed to put large amounts of the unemployed labouring poor to work, but also to be profit making, and so be attractive to potential investors (as we see in document 7 ). 


\section{Document 7:}

Sir John Sinclair has circulated a plan for establishing a Joint Stock Company, with a capital of one million, for the cultivation of the Waste Lands by spade husbandry. He say, it cannot be doubted, that 10,000 acres of land, lying entirely waste, may be purchased at a moderate rate; and he estimates the bringing them into cultivation as follows: -

First year.

Trenchering, 5/. per acre. $£ 50,000$ Manure, 15I. ditto 150,000 Seed, labour, and other expences 20,000

Second year.

Digging, 2l. 10s per acre 220,000 Manure, 5I. ditto. $£ 25,000$ See, labour, \&c 20,000

95,000

$£ 315,000$

The produce per acre, where spade husbandry is adopted, may be stated at 20l. per acre, or on 10,000 acres at 400,000l. for two years. Such is Sir John's plan for the employment of the poor; but the whole, he says, depends on the employment of a large capital in bringing the land into a state of thorough cultivation, and of great fertility; and the latter, he says, can easily be effected in the neighbourhood of London, where manure may be had cheap. (The London and Provincial Sunday Gazette and Political Inquisitor, $7^{\text {th }}$ February, 1819)

\section{4.ii Experimental Evidence and Spade Husbandry}

The spade husbandry debates had many axes as we have seen, and potentially crossed over into many other arguments. These elements came through in the agricultural experiments on spade husbandry, for these were not carried out independently of their political and farming contexts. The spade husbandry debate, in its experimental aspects, and 
judging by The Farmers' Journal, wound on over a considerable period from 1816 into the 1820s. First, recall (from Section 3.ii) the 1817 example of Mr A.L from Tetbury, and his experiments on the productive power of manure - which were significantly (it now seems) entitled "Method of Employing the Agricultural Poor". Further, on April $5^{\text {th }} 1819$ (front page, and p 106), Mr William Falla of Gateshead contributed a discursive account of a number of experiments. These include an accounting in which he extrapolates from his experiments on half an acre to provide calculations for an acre of wheat using an extremely labour intensive version of spade husbandry involving "transplanting 232,320 plants [wheat seedlings] at $4 \frac{1}{2} \mathrm{p}$ per 1000 " by hand! The monetary bottom line does not appear, though the correspondent claims a $30-40 \%$ increase in yield per plant. On January $10^{\text {th }} 1820$ (front page), "C.W.P. in Gainsborough" provides an example of calculations from hypothetical spade husbandry of the "garden" type. These calculations are hypothetical in the same kind of sense as Ricardo's numerical experiments: the husbandry did not actually take place, but the account has an air of credibility because of the exactitude of the numbers and pithy reporting. C.W.P's calculations are based on the idea of a cottager with 6 acres kept "in perfect garden neatness" that he believed could be scaled up to a small farm size.

On June $26^{\text {th }} 1820$ (again on the front page), in the same journal, an anonymous "Cultivator" of Hampshire reports his actual experiment on the use of spade labour in potato cultivation; while on November $6^{\text {th }} 1820$ ( $p$ 354) "Mr A. Rasp" reports his own experience on the advantages of manual over horse ploughing in working the soil, providing exact details of his cultivation methods for beans and the reasons he uses them in terms of the techniques of ploughing in relation to soil and rainfall. He also 
details the cost to himself and the good return in wages to the labourer from such cultivation as we see in document 8.

\section{Document 8:}

\begin{tabular}{|c|c|c|c|}
\hline Horse Ploughing & & Manual Labour & \\
\hline \multirow[t]{2}{*}{$\begin{array}{l}1^{\text {st }} \text { time, proverbially } \\
\text { brushing, man, boy , and } \\
\text { five horses, three quarters } \\
\text { an acre per day, at } 18 \mathrm{~s} . \text { per } \\
\text { day the team................... } \\
2 \mathrm{~d} \text { time, ploughing in the } \\
\text { seed, } \\
\text { ditto................................ } \\
\text { Two men to tread the } \\
\text { ground and level the land, } \\
\text { 1s. } 6 \mathrm{~d} . \text { each, and drink } 6 \mathrm{~d} . \\
\text { per acre..... } \\
\text { Extra seed, half a } \\
\text { bushel............. }\end{array}$} & $\begin{array}{l}£ 126 \\
126\end{array}$ & 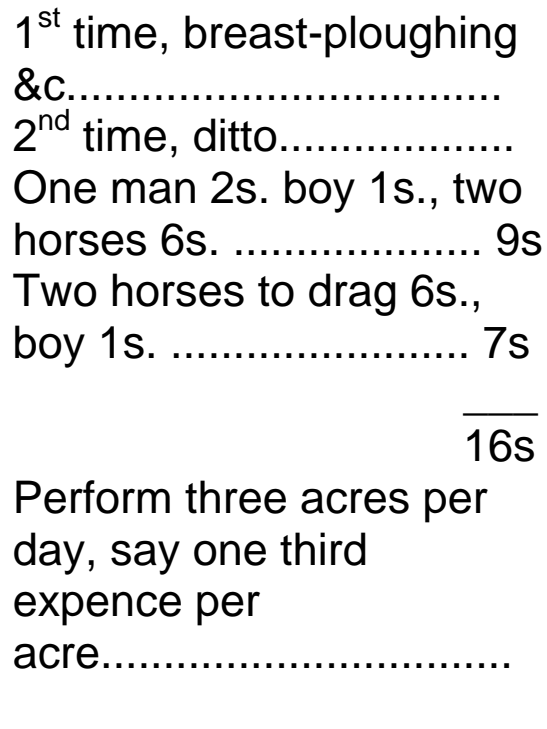 & $\begin{array}{rrr}£ 0 & 10 & 0 \\
0 & 5 & 0\end{array}$ \\
\hline & $£ 2144$ & Saving of expence …......... & $\begin{array}{rcr}£ 1 & 0 & 4 \\
1 & 14 & 0 \\
& & \\
£ 2 & 14 & 4\end{array}$ \\
\hline
\end{tabular}

I have not included water furrowing, they are so near alike in both ways. Impressed with these advantages, I trust it will not appear too enlightened to adhere to a system which gives for a period of three months, to the labourer nearly treble wages [25s weekly, when wages are 9s per week generally], and affords so self-evident a saving to myself.

By contrast, Mr J.L. James, writing in the edition of May $10^{\text {th }}, 1819$ (front page), on a field version of spade husbandry, reported his observations in a way which substitute lyric qualities for the prosaic details and serious accounting usually provided in these reports (see document 9). 


\section{Document 9:}

\section{To the Editor of The Farmers' Journal ON SPADE HUSBANDRY}

SIR,

On my route from Leamington to Cheltenham, I unexpectedly found myself within a quarter of a mile of Aston Somerville; and having read in your Journal Mr Crowther's letter on Spade Husbandry, with his invitation to all persons to witness its method and produce, I turned my horse with an intention of merely riding through his farm, but on coming into the parish, the whole of which I found was in his possession, I was so struck with the number of hands I saw bespangled over its fields, as it were like stars in the sky, that I resolved on a more minute examination. ......

I then saw a field, which this spring had been breast ploughed (what we call drenchering,) and burnt, and a number of men were then employed in breast-ploughing in the barley at 12s per acre, and it certainly left the land lighter and more likely to produce a great crop than if it had been ploughed with horses: the men I found could earn, some 10s., some 12s., and some $15 \mathrm{~s}$. weekly according as they were more or less expert hands. We then inspected several fields, about fifty or sixty acres of wheat, which it appeared had not been ploughed but twice in eight years, and it certainly had a most promising appearance. ... The whole parish seemed like a large machine, impelled by the prime mover, and all its subordinate parts performing their necessary offices with the regularity of wheels and pinions.

The utility of spade husbandry will not be decided by a solitary instance, but, if beneficial, will works its way by slow but sure degrees. In branching out of the turnpike road, I crossed the parish of Hintongreen, and from Somerville that of Worthington: if there is but little difference in the quality of the land in the three parishes, the superiority of Mr Crowther's crops must amply repay any extra expence in the cultivation, for they excel the former parish at the rate of three to one; and the latter, as two to one...

We find in these spade husbandry experimental reports an obvious contemporary reference point for Ricardo's arithmetic accounts of adding labour to fields. But it is also particularly notable that we find in this farming literature not only the reports of real agricultural experiments on this question, but also sets of accounts for the kind of hypothetical farming or scenario calculations that Ricardo himself used. The first most obvious difference in these accounts compared to Ricardo's numerical 
experiments are that the categories of rent and profit are not always separated out. In the contributions to the Farmers' Journal there tend to be only two factors: labourers and the farmer, suggesting perhaps that the contributors were yeoman farmers. In contrast, in the earlier 1814 Lords Report Evidence about the corn laws, witnesses were usually either tenant farmers or landlords' agents and generally separated out capital returns from rents in their accounts quite carefully. The second difference is that contributors to the debate, farmers or landowners, provided a commercial analysis showing their own profitability, not a general analysis of political economy in accordance with a theory of distribution as Ricardo was striving to do.

The spade husbandry debate petered out in the early 1820s, and judging from the discussion in the Farmers' Journal, it remained an open question whether, or perhaps under what local conditions, and for what crops, spade husbandry would show increasing yields (at least over some range) as labour input rose, or, as in Ricardo's numerical example, decreasing yields.

\section{$5 \quad$ Ricardo and the Political Economy of Spade Husbandry}

The census of population, begun in 1801 and continuing at 10 year intervals, had shown that, despite difficulties of comparison, population growth was a real issue. Certainly it could not be ignored by a landowner like Ricardo whose estates employed farm labourers and who was responsible for helping to support the unemployed of his parish in a period in which the new industrial opportunities for employment in factories were still limited. These structural shifts were exacerbated at the time Ricardo was formulating his theory of distribution by the short-term problems of agricultural distress when labourers were being laid off. For Ricardo, in 
his theoretical arguments with Malthus, the important issues had been understanding the effects of population growth on wages and economic growth, and understanding the dynamic relationship between wages and the well-being of labourers. Whereas technical change in agriculture appeared adequate in the short run to increase food output in line with population growth (despite Malthus's long-run dismal predictions), the increased workforce effect of population growth seemed a more immediately intractable and worrying problem. And it was certainly the problem which in the longer run, according to Ricardo's theory, had the power to reduce profits and so capital investment to zero: - with no investment, stagnation would, necessarily, follow. This was surely the fundamental reason why Ricardo used the example of adding more men to fields throughout his discussion of distribution issues, for it was this numerical experiment which crystallized his own dismal predictions in political economy.

The possibilities provided by spade husbandry seemed to offer a way out of stagnation as the necessary outcome of population growth. Ricardo certainly knew of these contemporary claims. The 1814 Lords Report did not mention spade husbandry by name, but several farmers attested that when they laid off extra labour following the fall in the price of corn, output would fall very significantly because of the loss of hoeing and suchlike activities and one farmer spoke of his experimental work on this matter. Ricardo knew not only the principle, but also the term "spade husbandry", by the time of the second edition of his Principles. He was no doubt familiar with Sinclair's make-work scheme for Sinclair was an important figure, President of the Board of Agriculture, well-known in political lobbies on behalf of agriculture and Ricardo continued to keep a keen eye on financial investment schemes. We know with certainty that Ricardo was familiar with the other make-work scheme by Robert Owen, 
whose 1819 plan for utopian new communities involved spade agriculture. Ricardo is on record as having said in the Houses of Parliament, that he supported the motion that there should be an inquiry into Owen's scheme for building his model communities - economic and social utopias precisely because he wanted to know the answer to the productivity questions raised in the debate: was spade husbandry productive and profitable or not? ${ }^{41}$ By 1820 , before the $3^{\text {rd }}$ edition of his book, he had commented on a section dealing with spade husbandry in Malthus's own forthcoming Principles. Malthus had written dismissively of the possibility that spade husbandry could ever "yield both a greater gross produce and a greater neat produce" or be a sensible use of capital and labour resources. ${ }^{42}$ Ricardo demurred in part, and while still professing himself unqualified to pronounce ${ }^{43}$ on the issues of spade husbandry, worked through a numerical example in which the switch to spade husbandry reduced output slightly, but was much to the benefit of the labourers since their consumption rose.

Ricardo therefore generally seems to have dismissed the possibility of the strong claim of the spade husbandrists (that there would be increasing returns with increasing labour), but himself also admits during the debate over the Owen scheme that he did not know the answer. Ricardo was not unreasonably sceptical on this matter, despite the increases in agricultural output that were even then taking place. But, in constructing his theory of distribution, Ricardo was constrained by a number of classical assumptions such as the labour theory of value and

\footnotetext{
${ }^{41}$ See Works, vol V, p 31 and 35.

${ }^{42}$ Ricardo's Works, vol II, p 237 quotes a footnote by Malthus to his own draft of the $2^{\text {nd }}$ edition of his Principles, which he had given Ricardo for comments.

${ }^{43}$ Ricardo several times protests his lack of knowledge of agricultural matters, but other examples from the Works suggest that he protests his innocence too much for credibility. For example - his exchange of letters with Maria Edgeworth about the Irish and their cultivation of potatoes reveals considerable knowledge about a subject on which he professed ignorance.
} 
assumption that all technical change must be labour saving, and his own more idiosyncratic theory of rent. These created some difficulty for him in fashioning the arithmetic cases for his Principles for they had to match his assumptions and speak to the contemporary agricultural problem of unemployed labourers. He solved this problem in his numerical experiments by adding labourers to fields, though still with declining returns to the additional labourers. This was the case that formed the basis of his theory of distribution, so that, in effect, if we follow his argument through his numerical cases, we find that Ricardo's working out of his theory of distribution depended upon rejecting the strong productivity claims offered for spade husbandry.

\section{Conclusion}

Ricardo is usually regarded as the one of the first of the modern economists, for, despite his Classical economics beliefs, his method of arguing in his main work on political economy (his Principles) is seen to be deductive and so logical rather than discursive and dependent upon historical examples. His arguments may not have been formulated in mathematics, but, so modern economists believe, they could easily have been, for his verbal arguments are conducted so meticulously, and because he appears to argue at a more abstract, hypothetical level than his contemporaries. Such commentators have largely ignored the importance of his numerical casework. By paying attention to these numerical accountings, I have shown how Ricardo's theorizing was dependent upon these little numerical experiments, and they are particularly important in providing the place where he developed his theory of distribution between the classes. More broadly we can see that they provided the scope for theorizing in the sense of providing a tool to 
try out his ideas and to demonstrate his findings. Such methods began to form a mode of argument amongst his contemporaries, and for some later economists of the classical school (for example: Marx, but not J.S. Mill). ${ }^{44}$ Although there seems to be no continuous transmission or transformation from these into mathematical modes of arguing, these numerical experiments can be seen as a nascent form of economic modelling, the method of doing economics which came to dominance only 100-150 years later.

These numerical experiments are equally important in themselves. On the one hand, they provide evidence for re-evaluation of Ricardo's approach. They show that far from working out his grand theories in the abstract, hypothetical, realm, he not only made use of standard empirics of the day in the numbers he used, but also he used them to depict central farming decisions about investment and technical change for the period that he lived in. We know that he addressed real economic problems of his day, but these numerical reasonings show us how closely these problems were formulated in terms of the everyday issues faced by farmers and in terms of the immediate policy debates of the day. On the other hand, we have also seen that Ricardo's numerical accounts mirrored the experimental reports of the farming of the time, both in similarities of treatments applied and in the ways in which the experiments were reported by laying out the farming accounts for his numerical experiments. Ricardo's arithmetic experiments were well attached to his world in both these senses, thus his laws of distribution were derived not so much through abstract and hypothetical reasoning, but from his own experience and understanding of the agricultural economy using numerical versions of experimental farming.

${ }^{44}$ On Marx's use of numerical cases, see Reuten (1999). 
Bibliography

Allen, Robert (1994) "Agriculture During the Industrial Revolution" in The Economic History of Britain since 1700, Vol I: 1700-1860; ed R. Floud and D. McCloskey (Cambridge: Cambridge University Press), pp 96-122.

Barkai (1959) "Ricardo on Factor Prices and Income Distribution in a Growing Economy" Economica, 26, 240-50.

Beatson, Alexander (1820/1) A New System of Cultivation

Blaug, Mark (1956) "The Empirical Content of Ricardian

Economics" Journal of Political Economy, 64, 41-58.

Blaug, Mark (1958) Ricardian Economics (New Haven: Yale University

Press)

Brunt, Liam (forthcoming) "Arthur Young and the Inception of the

Social Science Survey" (Nuffield College, Oxford).

Cunningham Wood, John (1985-1994) David Ricardo: Critical

Assessments 7 Volumes (London: Croom Helm/Routledge).

Davy, Humphry (1813) Elements of Agricultural Chemistry (London:

Longman, Orme, Brown, Green, and Longmans).

Dorfman, Robert (1989) "Thomas Robert Malthus and David Ricardo" Journal of Economic Perspectives, 3:3, 153-64.

Goddard, Nicholas (1989) "Agricultural Literature and Societies" Chapter III in Mingay (ed) (1989).

Gootzeit, Michael J. (1975) David Ricardo (New York: Columbia University Press)

Grisenthwaite, William (1819) A New Theory of Agriculture Herbert, N.M. (1976) ed: Victoria County History of Gloucestershire. Vol $X I$, The Stroud Valleys, ed. (Oxford: Oxford University Press/University of London). 
Henderson, John P. with John B. Davis (1997) The Life and Economics of David Ricardo (Boston: Kluwer).

Hilton, Boyd (1977) Corn, Cash, and Commerce: The Economic Policies of the Tory Governments, 1815-1830 (Oxford).

Hollander, Samuel (1979) The Economics of David Ricardo, (University of Toronto Press; London: Heinemann).

House of Lords (1814) "First and Second Reports from the Lords Committee appointed to enquire into the state of the Growth, Commerce and Consumption of Grain, and all laws relating thereto." $25^{\text {th }}$ July, 1814, Parliamentary Papers, 1814-5, Vol V.

James, Patricia (1979) Population Malthus: His Life and Times (London: Routledge and Kegan Paul).

Malthus, Thomas R. (1814) "Observations on the Effects of the Corn Laws" (reprinted in The Pamphlets of Thomas Robert Malthus (New York: Kelley) 1970).

Malthus, Thomas R. (1815) "An Inquiry into the Nature and Progress of Rent" (reprinted in The Pamphlets of Thomas Robert Malthus (New York: Kelley) 1970).

Malthus, Thomas R. (1920) Principles of Political Economy considered with a view to their Practical Applications (London).

Marshall, William (1779) Experiments and Observations Concerning Agriculture and the Weather

Marshall, William (1817/1968) The Review and Abstract of the Country Reports to the Board of Agriculture, $5^{\text {th }}$ Volume (New York: Augustus Kelley).

Mingay, Gordon E. (1975) Arthur Young and His Times (London: MacMillan). 
Mingay Gordon E. (1977) The Agricultural Revolution: Changes in Agriculture, 1650-1880 Documents in Economic History Series (London: Adam and Charles Black).

Mingay, Gordon E. (1989) The Agrarian History of England and Wales Vol VI: 1750-1850 (Cambridge: Cambridge University Press).

Mingay, Gordon E. (1997) Parliamentary Enclosure in England (London: Longman)

Mitchell, B.R. And Phyllis Deane (1971) Abstract of British Historical Statistics (Cambridge: Cambridge University Press).

O'Brien, Dennis P. (1975) The Classical Economists (Oxford: Clarendon Press).

O'Brien, Dennis P. (1981) "Ricardian Economics and the Economics of David Ricardo" Oxford Economic Papers, 33, 352-86.

Overton, Mark (1996) Agricultural Revolution in England: The Transformation of the Agrarian Economy, 1500-1850 (Cambridge: Cambridge University Press)

Ramana, D.V. (1957) "Ricardo's Environment" Indian Journal of Economics 38, 151-64.

Reich, M (1980) "Empirical and Ideological Elements in the Decline of

Ricardian Economics" Review of Radical Political Economics, 12:3, 1-14.

Reuten, G. (1999) "Knife-edge Caricature Modelling: The Cae of Marx's Reproduction Schema" in Mary S. Morgan and Margaret Morrison (eds) Models as Mediators (Cambridge: Cambridge University Press).

Ricardo, David (1815) "The Influence of a low Price of Corn on the Profits of Stock" (in Sraffa, Vol IV) 
Ricardo, David (1821) The Principles of Political Economy and Taxation (Everyman edition, 1973; London: Dent. As edited by Sraffa, see Sraffa, 1951)

Ricardo, David (Collected Works - see Sraffa)

Russell, John E. (1966) A History of Agricultural Science in Great Britain, 1620-1954 (London: Allen and Unwin).

Smith, Adam (1776) The Wealth of Nations (Everyman edition, 1910/1991) (London: Random)

Sraffa, Piero (1951-1973) The Works and Correspondence of David Ricardo (Edited with the collaboration of M.H. Dobb) (Cambridge: Cambridge University Press for The Royal Economic Society) Torrens, Robert (1815) Essay on the External Corn Trade (London) Turner, Michael E. J.V. Beckett and A. Afton (1997) Agricultural Rents in England, 1690-1914 (Cambridge: Cambridge University Press)

Weatherall, David (1976) David Ricardo: A Biography (The Hague: Matinus Nijhoff).

West, Edward (1815/1903) Essay on the Application of Capital to Land (Reprints of Economic Tracts, Series 1, No 3, Baltimore: Johns Hopkins University)

Winch, Donald (1996) Riches and Poverty: An Intellectual History of Political Economy in Britain, 1750-1834 Ideas in Context, 39 (Cambridge: Cambridge University Press). 


\section{LONDON SCHOOL OF ECONOMICS}

\section{DEPARTMENT OF ECONOMIC HISTORY}

WORKING PAPERS IN - THE NATURE OF EVIDENCE: HOW WELL DO "FACTS" TRAVEL?

For further copies of this, and to see other titles in the department's group of working paper series, visit our website at:

http://www.Ise.ac.uk/collections/economichistory/

01/05: Transferring Technical Knowledge and Innovating in Europe, c.1200-c.1800 Stephan R. Epstein

02/05: A Dreadful Heritage: Interpreting Epidemic Disease at Eyam, 1666-2000

Patrick Wallis

03/05: Experimental Farming and Ricardo's Political Arithmetic of Distribution

Mary S. Morgan 